\title{
Erratum to: Video-assisted anal fistula treatment (VAAFT): a novel sphincter-saving procedure for treating complex anal fistulas
}

\author{
P. Meinero $\cdot$ L. Mori
}

Published online: 10 January 2012

(C) Springer-Verlag 2011

Erratum to: Tech Coloproctol (2011) 15:417-422

DOI 10.1007/s10151-011-0769-2

In the original published article the following paragraph:

"Conflict of interest: The authors have declared that no conflict of interest exists"

was erroneously added by the publisher after proof reading. The authors declared that a conflict of interest existed by stating that

“This study was supported by Karl Storz GmbH \& Co in the form of grants and equipment. The senior author, Piercarlo Meinero, has a patent license agreement with Karl Storz GmbH \& Co concerning the fistuloscope kit"

but this statement was placed under "Acknowledgements".

The online version of the original article can be found under doi:10.1007/s10151-011-0769-2.

P. Meinero $(\bowtie) \cdot$ L. Mori

Department of General Surgery, Proctology Unit,

E. Riboli Hospital, ASL 4 Chiavarese,

Via Don Bobbio 25, 16033 Lavagna, Genoa, Italy

e-mail: pmeinero@as14.liguria.it 